\title{
Phylogenetic, Morphological, and Pathogenic Characterization of Alternaria Species Associated with Fruit Rot of Blueberry in California
}

\author{
X. Q. Zhu and C. L. Xiao \\ First author: Department of Plant Pathology, China Agricultural University, Beijing, 100193, China; and first and second authors: U.S. \\ Department of Agriculture-Agricultural Research Service, San Joaquin Valley Agricultural Sciences Center, 9611 South Riverbend Ave., \\ Parlier, CA 93648. \\ Accepted for publication 27 July 2015.

\begin{abstract}
Zhu, X. Q., and Xiao, C. L. 2015. Phylogenetic, morphological, and pathogenic characterization of Alternaria species associated with fruit rot of blueberry in California. Phytopathology 105:1555-1567.

Fruit rot caused by Alternaria spp. is one of the most important factors affecting the postharvest quality and shelf life of blueberry fruit. The aims of this study were to characterize Alternaria isolates using morphological and molecular approaches and test their pathogenicity to blueberry fruit. Alternaria spp. isolates were collected from decayed blueberry fruit in the Central Valley of California during 2012 and 2013. In total, 283 isolates were obtained and five species of Alternaria, including Alternaria alternata, A. tenuissima, A. arborescens, A. infectoria, and A. rosae, were identified based on DNA sequences of the plasma membrane ATPase, Alt al and Calmodulin gene regions in combination with morphological characters of the culture and sporulation. Of the 283 isolates, $61.5 \%$ were

identified as A. alternata, $32.9 \%$ were A. arborescens, $5.0 \%$ were A. tenuissima, and only one isolate of A. infectoria and one isolate of A. rosae were found. These fungi were able to grow at temperatures from 0 to $35^{\circ} \mathrm{C}$, and mycelial growth was arrested at $40^{\circ} \mathrm{C}$. Optimal radial growth occurred between 20 to $30^{\circ} \mathrm{C}$. Pathogenicity tests showed that all five Alternaria spp. were pathogenic on blueberry fruit at 0,4 , and $20^{\circ} \mathrm{C}$, with $A$. alternata, $A$. arborescens, and A. tenuissima being the most virulent species, followed by A. infectoria and A. rosae. Previously A. tenuissima has been reported to be the primary cause of Alternaria fruit rot of blueberry worldwide. Our results indicated that the species composition of Alternaria responsible for Alternaria fruit rot in blueberry can be dependent on geographical region. A. alternata, A. arborescens, A. infectoria, and A. rosae are reported for the first time on blueberry in California. This is also the first report of A. infectoria and A. rosae infecting blueberry fruit.
\end{abstract}

Highbush blueberry (Vaccinium corymbosum L.) fruit are known for their rich antioxidants, vitamins, and fiber and are becoming popular around the world, and production has steadily increased, with $87 \%$ blueberry production occurring in North America (Anonymous 2011; Caruso and Ramsdell 2007). Historically, the Central Valley of California is not known for production of blueberries because of mild winter weather in the region. However, recent establishment of low-chill southern highbush blueberry cultivars in California's warm climate has significantly increased the acreage of blueberry production in Central California, which is now a major southern highbush blueberry production region in the United States (Jimenez et al. 2005). The vast majority of blueberries grown in California are destined for the fresh market, with a 2013 production value of $\$ 127$ million (USDA-National Agricultural Statistics Service 2014). As the production continues to grow, the blueberry industry has a need to prolong the storage life of blueberry in order to extend marketing period and increase exports. However, the postharvest life of blueberry fruit is limited by fruit rots caused by fungal pathogens (Cappellini et al. 1982; Mehra et al. 2012).

The major fungi responsible for postharvest fruit rots of blueberries are Alternaria spp., Botrytis cinerea, Colletotrichum acutatum, C. gloeosporioides, and Gloeosporium minus (Cline 1996; Lambert 1990; Mehra et al. 2012; Milholland and Jones 1972). Previous research indicated that $A$. tenuissima is the primary causal agent of Alternaria fruit rot of blueberry (Cline 1996; Greco et al. 2012; Mehra et al. 2012; Milholland and Jones 1972; You et al.

Corresponding author: C. L. Xiao; E-mail address: Chang-Lin.Xiao@ars.usda.gov

http://dx.doi.org/10.1094/PHYTO-05-15-0122-R

This article is in the public domain and not copyrightable. It may be freely reprinted with customary crediting of the source. The American Phytopathological Society, 2015
2013). However, most Alternaria spp., including A. tenuissima, exhibit considerable morphological similarities. Moreover, there are several small-spored Alternaria spp. with morphological characteristics that overlap those of $A$. tenuissima; the most commonly known is A. alternata. During a survey for postharvest diseases of blueberries grown in the Central Valley of California conducted during 2012 to 2013, we observed that Alternaria rot is a significant problem and there is considerable variation among the small-spored Alternaria spp. isolates recovered from decayed blueberry fruit (C. L. Xiao, unpublished data). Thus, we initiated a study to characterize the Alternaria species profile in blueberry in California. Understanding species composition is important to the development of relevant disease control practices as different species of Alternaria may respond to fungicides differently (Ma et al. 2003; Rosenzweig et al. 2008).

In addition to the use of morphological characters to differentiate Alternaria species, with the advancement of molecular techniques and DNA sequencing, research on taxonomy of Alternaria was conducted using multigene phylogentic analyses based on sequences of internal transcribed spacer (ITS), the second largest subunit of RNA polymerase II (RPB2), chitin synthase, $T s r 1$, translation elongation factor $(T E F)$, plasma membrane ATPase, Alternaria major allergen (Alt al), glyceraldehyde-3-phosphate dehydrogenase ( $g p d)$, beta-tubulin, actin, Calmodulin, and partial coding sequence of histone 3 gene, etc. (Andrew et al. 2009; Deng et al. 2012; Greco et al. 2012; Hong et al. 2005; Jasnic et al. 2011; Lawrence et al. 2013; Luan et al. 2007; Wang et al. 2014; Woudenberg et al. 2013; You et al. 2013). Among those genes or regions, Alt al and gpd are commonly used. In this study, we downloaded sequences of some small-spored Alternaria species, including A. alternata, A. tenuissima, A. arborescens, and A. infectoria from GenBank and compared them, and we found that the sequences of the plasma membrane ATPase are informative in 
differentiating those Alternaria species. Thus, in this study we selected plasma membrane ATPase, Alt al, and Calmodulin genes or regions to differentiate our Alternaria spp. isolates from blueberries.

The objectives of this study were to (i) determine the species profiles of Alternaria associated with decayed blueberry fruit using molecular phylogenetic and morphological approaches and (ii) test pathogenicity of isolates representative for several Alternaria spp. on blueberry fruit.

\section{MATERIALS AND METHODS}

Collection of isolates. In 2012 and 2013, harvested blueberry fruit were obtained from commercial blueberry fruit packing operations. The fruit were stored at $0^{\circ} \mathrm{C}$ for 5 weeks, and decayed fruit were selected for isolation of fungal pathogens. Decayed fruit were sprayed with $70 \%$ ethanol until runoff and allowed to dry. The symptomatic tissue just behind the advancing lesion margin was excised using a sterile scalpel and placed in petri dishes containing potato dextrose agar (PDA) (Difco Laboratories, Detroit) acidified with lactic acid (4 $\mathrm{ml}$ of $25 \%$ [vol/vol] per liter of medium) to minimize bacterial growth. Isolation plates were incubated at room temperature $\left(20\right.$ to $21^{\circ} \mathrm{C}$ ) for 7 to 14 days, and Alternaria-like colonies were subcultured to new acidified PDA for 3 to 4 days. Pure cultures were then cultured on PDA. In total, 283 Alternaria spp. isolates were obtained in this study.

To obtain single-spored cultures, the method described by Zhu et al. (2011) was used with some modifications. Specifically, conidia were taken from sporulating colonies cultured for 7 to 14 days using an inoculation loop and then streaked onto $2 \%$ water agar plates. The plates were incubated for 18 to $20 \mathrm{~h}$ at $22^{\circ} \mathrm{C}$ to allow for conidial germination, and germinating conidia were transferred under a dissecting microscope to a new PDA plate. After 7 days of incubation, mycelial plugs of those isolates were cut and stored in $15 \%$ glycerol at $-80^{\circ} \mathrm{C}$. Eight isolates of Alternaria spp. that were isolated from pistachio in the same region and provided by T. Michailides at the University of California, Kearney Agricultural Research and Extension Center (Pryor and Michailides 2002), including A. alternata (03.I95, 03.J32), A. tenuissima (03.J11, 03. $\mathrm{J} 12$ ), A. arborescens (03.J24, 03.J29), and A. infectoria (03.J08, 03. J14), were used for comparison (Table 1).

DNA extraction, PCR amplification, and sequencing. In this study, all 283 Alternaria spp. isolates were initially identified

TABLE 1. Sources and GenBank accession numbers of sequences of three genes (plasma membrane ATPase, Alt al, and Calmodulin) of Alternaria spp. isolated from blueberry used for phylogenetic analysis, pathogenicity tests and temperature response study

\begin{tabular}{|c|c|c|c|c|c|c|}
\hline \multirow[b]{2}{*}{ Name in GenBank } & \multirow[b]{2}{*}{ Isolate } & \multirow[b]{2}{*}{ Location } & \multirow[b]{2}{*}{ Collection date (mm/dd/yyyy) } & \multicolumn{3}{|c|}{ Accession number } \\
\hline & & & & Plasma membrane ATPase & Alt al & Calmodulin \\
\hline Alternaria alternata & $\mathrm{X} 1020^{\mathrm{x}, \mathrm{y}}$ & Delano, CA & $5 / 16 / 2013$ & KJ908221 & KJ921010 & KJ920963 \\
\hline A. alternata & $\mathrm{X} 1048^{\mathrm{y}}$ & Delano, CA & $4 / 10 / 2013$ & KJ908230 & KJ920997 & KJ920957 \\
\hline A. alternata & $\mathrm{X} 1432^{\mathrm{y}}$ & Delano, CA & $6 / 7 / 2013$ & KJ908223 & KJ921014 & KJ920966 \\
\hline A. alternata & X1431 & Stockton, CA & $6 / 7 / 2013$ & KJ908255 & KJ920985 & KJ920965 \\
\hline A. alternata & $\mathrm{X} 1280$ & Tulare, CA & $6 / 6 / 2013$ & KJ908252 & KJ920986 & KJ920971 \\
\hline A. alternata & X1040 & Kingsburg, CA & $5 / 16 / 2013$ & KJ908251 & KJ920983 & KJ920972 \\
\hline A. alternata & X1092 & Kingsburg, CA & $5 / 16 / 2013$ & KJ908256 & KJ920988 & KJ920968 \\
\hline A. alternata & X1104 & Kingsburg, CA & $5 / 16 / 2013$ & KJ908254 & KJ920984 & KJ920969 \\
\hline A. alternata & X1111 & Kingsburg, CA & $5 / 16 / 2013$ & KJ908233 & KJ920999 & KJ920958 \\
\hline A. alternata & X1122 & Kingsburg, CA & $5 / 16 / 2013$ & KJ908253 & KJ920989 & KJ920970 \\
\hline A. alternata & X1191 & Kingsburg, CA & $5 / 31 / 2013$ & KJ908234 & KJ920991 & KJ920956 \\
\hline A. alternata & $\mathrm{X} 1265^{\mathrm{x}, \mathrm{y}}$ & Kingsburg, CA & $6 / 6 / 2013$ & KJ908237 & KJ921004 & KJ920960 \\
\hline A. alternata & $X 1269^{y}$ & Kingsburg, CA & $6 / 6 / 2013$ & KJ908238 & KJ921005 & KJ920961 \\
\hline A. alternata & X1283 & Kingsburg, CA & $6 / 6 / 2013$ & KJ908222 & KJ921015 & KJ920938 \\
\hline A. arborescens & X1312 & Richgrove, CA & $8 / 2 / 2013$ & KJ908242 & KJ921008 & KJ920948 \\
\hline A. arborescens & $\mathrm{X} 1033^{\mathrm{x}, \mathrm{y}}$ & Delano, CA & $5 / 16 / 2013$ & KJ908248 & KJ921009 & KJ920941 \\
\hline A. arborescens & X1205 & Delano, CA & $5 / 28 / 2013$ & KJ908225 & KJ921002 & KJ920939 \\
\hline A. arborescens & $\mathrm{X} 1263^{\mathrm{y}}$ & Delano, CA & $6 / 7 / 2013$ & KJ908226 & KJ921003 & KJ920947 \\
\hline A. arborescens & $\mathrm{X} 945^{\mathrm{y}}$ & Delano, CA & $3 / 18 / 2013$ & KJ908228 & KJ920995 & KJ920943 \\
\hline A. arborescens & $\mathrm{X} 1276^{\mathrm{y}}$ & Stockton, CA & $6 / 6 / 2013$ & KJ921006 & KJ921006 & KJ920945 \\
\hline A. arborescens & $\mathrm{X} 100^{\mathrm{x}, \mathrm{y}}$ & Kingsburg, CA & $8 / 10 / 2012$ & KJ908224 & KJ921013 & KJ920950 \\
\hline A. arborescens & X1013 & Kingsburg, CA & $5 / 16 / 2013$ & KJ908247 & KJ920987 & KJ920949 \\
\hline A. arborescens & X1126 & Kingsburg, CA & $5 / 16 / 2013$ & KJ908245 & KJ920990 & KJ920940 \\
\hline A. arborescens & X1392 & Kingsburg, CA & $5 / 16 / 2013$ & KJ908246 & KJ920992 & KJ920946 \\
\hline A. infectoria & $\mathrm{X} 1273^{\mathrm{x}, \mathrm{y}}$ & Tulare, CA & $6 / 6 / 2013$ & KJ908218 & KJ920982 & KJ920953 \\
\hline A. rosae & $\mathrm{X} 1272^{\mathrm{x}, \mathrm{y}}$ & Tulare, CA & $6 / 6 / 2013$ & KJ908217 & KJ920981 & KJ920952 \\
\hline A. tenuissima & $\mathrm{X} 1003^{\mathrm{y}}$ & Delano, CA & $4 / 4 / 2013$ & KJ908229 & KJ920996 & KJ920954 \\
\hline A. tenuissima & $\mathrm{X} 1026^{\mathrm{x}, \mathrm{y}}$ & Delano, CA & $5 / 16 / 2013$ & KJ908240 & KJ921011 & KJ920944 \\
\hline A. tenuissima & $\mathrm{X} 1068^{\mathrm{y}}$ & Delano, CA & $5 / 1 / 2013$ & KJ908231 & KJ920998 & KJ920962 \\
\hline A. tenuissima & X1309 & Delano, CA & $6 / 7 / 2013$ & KJ908241 & KJ921007 & KJ920942 \\
\hline A. tenuissima & $\mathrm{X} 1085$ & Kingsburg, CA & $6 / 5 / 2013$ & KJ908232 & KJ920993 & KJ920967 \\
\hline A. tenuissima & X1099 & Kingsburg, CA & $5 / 16 / 2013$ & KJ908227 & KJ920994 & KJ920951 \\
\hline A. tenuissima & $\mathrm{X} 1125^{\mathrm{y}}$ & Kingsburg, CA & $5 / 16 / 2013$ & KJ908235 & KJ921000 & KJ920959 \\
\hline A. tenuissima & X1147 & Kingsburg, CA & $5 / 23 / 2013$ & KJ908236 & KJ921001 & KJ920955 \\
\hline A. tenuissima & $\mathrm{X} 1259^{\mathrm{x}, \mathrm{y}}$ & Kingsburg, CA & $6 / 7 / 2013$ & KJ908216 & KJ921012 & KJ920964 \\
\hline A. alternata & $03.195^{z}$ & $\mathrm{CA}$ & 6/6/1990 & KJ908249 & KJ921021 & KJ920976 \\
\hline A. alternata & 03.J32 & $\mathrm{CA}$ & 9/9/1998 & KJ908250 & KJ921020 & KJ920975 \\
\hline A. arborescens & 03.J29z & $\mathrm{CA}$ & 9/9/1998 & KJ908243 & KJ921022 & KJ920980 \\
\hline A. arborescens & 03.J $24^{z}$ & $\mathrm{CA}$ & 9/9/1998 & KJ908244 & KJ921023 & KJ920979 \\
\hline A. infectoria & $03 . J 14^{z}$ & $\mathrm{CA}$ & 9/9/1998 & KJ908219 & KJ921017 & KJ920977 \\
\hline A. infectoria & 03.J08 & $\mathrm{CA}$ & 9/9/1998 & KJ908220 & KJ921016 & KJ920978 \\
\hline A. tenuissima & 03.J11 $1^{\mathrm{z}}$ & $\mathrm{CA}$ & 9/9/1998 & KJ908258 & KJ921019 & KJ920974 \\
\hline A. tenuissima & $03 . \mathrm{J} 12^{\mathrm{z}}$ & $\mathrm{CA}$ & 9/9/1998 & KJ908257 & KJ921018 & KJ920973 \\
\hline
\end{tabular}

${ }^{\mathrm{x}}$ Isolates used for pathogenicity tests on blueberry fruit and temperature response.

${ }^{y}$ Isolates used for the test of mycelial growth rate and measurement of conidia size.

${ }^{\mathrm{z}}$ Reference isolates from pistachio provided by T. J. Michailides at the University of California, Davis. 
by amplifying the plasma membrane ATPase gene and by comparing results to sequences in GenBank. Based on plasma membrane ATPase gene sequences (see below for the detail), a subset of 27 isolates, representing different species of Alternaria, the range of genetic diversity and geographic origin (Table 1) were further sequenced for Alt al gene and Calmodulin gene.

Mycelia and spores from 7- to 10-day-old PDA cultures incubated at $20^{\circ} \mathrm{C}$ were used for DNA extraction. Genomic DNA was extracted using DNeasy Plant Mini Kit (Qiagen, Valencia, CA) and FastPrep-24 Instrument following the manufacturer's instructions (MP Biomedicals, Santa Ana, CA). DNA concentration was quantified using NanoDrop 2000c (Thermo Scientific, Wilmington, DE).

Amplifications of fragments of plasma membrane ATPase and Calmodulin genes were performed using primer pairs ATPDF1/ ATPDR1 and CALDF1/CALDR1, respectively (Lawrence et al. 2014). Amplification of the Alt al gene was performed using primer pairs Alt-for/Alt-rev described in Hong et al. (2005). PCR amplification was conducted in a $25-\mu$ reaction volume containing $12.5 \mu \mathrm{l}$ of GoTaq Mix (Promega, Madison, WI), $1 \mu \mathrm{l}$ of each primer $(10 \mu \mathrm{M})$, and $1 \mu \mathrm{l}(20$ to $30 \mathrm{ng})$ of template DNA. PCR reactions were carried out in a thermal cycler S1000 (Bio-Rad Laboratory, Forster City, CA). The thermocycling parameters for the plasma membrane ATPase gene were the same as described by Lawrence et al. (2013): an initial heating step at $94^{\circ} \mathrm{C}$ for $4 \mathrm{~min}$, followed by 35 cycles of denaturation at $94^{\circ} \mathrm{C}$ for $30 \mathrm{~s}$, annealing at temperature gradient of $59^{\circ} \mathrm{C}$ for $30 \mathrm{~s}$ and extension at $72^{\circ} \mathrm{C}$ for $1 \mathrm{~min}$; and final extension at $72^{\circ} \mathrm{C}$ for $5 \mathrm{~min}$. The thermocycling parameters for Alt $a l$ and Calmodulin genes were the same as described by Hong et al. (2005): an initial heating step at $95^{\circ} \mathrm{C}$ for $5 \mathrm{~min}$, followed by 35 cycles of denaturation at $95^{\circ} \mathrm{C}$ for $40 \mathrm{~s}$, annealing at temperature gradient of $57^{\circ} \mathrm{C}$ for $40 \mathrm{~s}$ and extension at $72^{\circ} \mathrm{C}$ for $1 \mathrm{~min}$; and final extension at $72^{\circ} \mathrm{C}$ for $10 \mathrm{~min}$. PCR products were separated by electrophoresis in $1 \%$ agarose gels in $1.0 \times$ Tris borate EDTA (TBE) buffer and photographed. PCR products were then purified using GeneJet purification kit (Thermo Fisher Scientific, Pittsburgh, PA) following the manufacturer's instructions. PCR products were quantified using Nanodrop 2000c (Thermo Scientific) and diluted to a range between 5 and $15 \mathrm{ng} / \mu \mathrm{l}$ for sequencing, depending on the length of the PCR products.

The PCR products were sequenced in both directions using the PCR primers and ABI Prism BigDye Terminator v. 3.1 cycle Sequencing Kit in a $3130 \times$ L Genetic Analyzer (Applied Biosystems, Foster City, CA) according to the manufacturer's instructions. The nucleotide sequences were read with an ABI Prism $3130 \times \mathrm{L}$ sequencer (Applied Biosystems) and software Bioedit 7.0.4.1 (Hall 1999). Sequences obtained in this study were deposited in GenBank (Table 1).

Phylogenetic analyses. To obtain preliminary identification for the isolates in this study, the plasma membrane ATPase, Calmodulin and Alt al sequences were subjected to BLAST search using the National Center for Biotechnology Information (NCBI, http://www.ncbi.nlm.nih.gov) nucleotide database. Sequences of the type species specimen strains for closely related Alternaria species were obtained from GenBank (http://www.ncbi.nlm.nih. gov) to compile datasets for phylogenetic analyses (Table 2). Sequences for each of the three gene regions were aligned using DNAMAN version 7 (Lynnon Corporation). Sequence alignments for each of the three gene regions were manually edited in DNAMAN 7.0 and deposited in TreeBase (http://www.treebase.org).

Maximum parsimony (MP) phylogenetic analyses were performed for each of the plasma membrane ATPase, Calmodulin, and Alt al datasets as well as for the combined datasets of the three genes in PAUP* $4.0 b 10$ (Swofford 2000). Gaps were treated as missing data. Trees were inferred using the heuristic search with TBR branch swapping and 1,000 random sequence additions. Maxtrees were unlimited, branches of zero length were collapsed, and all multiple parsimonious trees were saved. Branch stability was evaluated in a bootstrap analysis with 1,000 replicates, each with 100 replicates of random stepwise addition of taxa. A second phylogenetic analysis using Markov Chain Monte Carlo (MCMC) algorithm was conducted to generate trees with Bayesian posterior probabilities in MrBayes v3.1.2 (Ronquist and Huelsenbeck 2003). Nucleotide substitution models were determined using Modeltest $\mathrm{v}$ 3.7 (Posada and Crandall 1998) for each gene region and included in the analyses. Two analyses of four MCMC chains were run from random trees for 10 million generations and sampled every 1,000 generations. The first $25 \%$ of trees were discarded as the burn-in phase of each analysis and posterior probabilities determined from the remaining tree. The phylogenetic trees were viewed and printed using Treeview 1.6.6 (Page 1996).

Morphological observations. In total, 17 isolates representing different Alternaria species in the phylogenetic analysis were studied for morphological characteristics (Table 1). To observe the colony morphology, selected isolates were cultured on PDA for 7 days and then transferred to petri dishes containing PDA (Pryor and Michailides 2002) or potato carrot agar (PCA) (Simmons 2007). For each isolate, three replicate plates were used. These cultures were incubated at $22^{\circ} \mathrm{C}$ under cool white fluorescent light with an $8 \mathrm{~h}$ photoperiod and $16 \mathrm{~h}$ darkness. Colony diameters were measured at two perpendicular directions 3 and 5 days after inoculation. For each of the tested isolates, the average colony growth per day between 3 to 5 days was then calculated. After 7 days, cultures were examined for colony color, colony margin, colony texture, and the development of pigments or crystals in the agar medium. Colony color was determined based on color standards of Ridgway (1912). The experiment was performed twice.

To observe sporulation patterns, isolates were cultured on PDA for 7 days and then transferred to petri dishes containing PCA, 0.05x PDA (Pryor and Michailides 2002), or synthetic nutrient agar (SNA) (Woudenberg et al. 2013). Dishes were incubated for 7 days under the same conditions as described above. After incubation, cultures were examined under a dissecting microscope for characteristics of the sporulation apparatus, including length of conidial chains, presence of elongated secondary conidiophores, and manner by which branching of conidial chains occurred. The sellotape technique was used for making slide preparations (Woudenberg et al. 2013) with Shear's medium as mounting fluid. Photographs of characteristic structures such as conidial chains and conidia were made under a compound microscope. For each isolate, the dimensions (length and width) of 50 conidia were measured. Average (mean), standard error, and minimum and maximum measurements were calculated for each isolate. Conidial shape and color and septation were also recorded.

On the basis of preliminary results, colony color of Alternaria spp. was more evident on PDA than on PCA. Sporulation of Alternaria spp. on PCA was more abundant than that on PDA and SNA. Thus, we selected PDA for observation of colony color development and PCA as the medium for further study of sporulation in order to compare the sporulation characteristics with published results from other studies.

Effect of temperature on mycelial growth. Effects of temperature on mycelial growth were evaluated on PDA (Pryor and Michailides 2002). Two isolates for each species were used in this study. Isolates were grown on PDA at $20^{\circ} \mathrm{C}$ in the dark for 7 days. Mycelial plugs (4 $\mathrm{mm}$ diameter) were removed with a sterile cork borer (4 $\mathrm{mm}$ in diameter) from the leading edges of colonies, and one such plug was placed in the center of each $90 \mathrm{~mm}$ Petri plate containing the medium. Inoculated plates were placed in plastic boxes and incubated at $0,5,10,15,20,25,30,35$, or $40^{\circ} \mathrm{C}$ in the dark. There were three replicate plates for each isolate at each temperature. Colony diameter in each plate was measured at two perpendicular directions after 3 and 5 days of inoculation at 10,15, $20,25,30$, and $35^{\circ} \mathrm{C}, 10$ and 20 days after inoculation at 0 and $5^{\circ} \mathrm{C}$; the two measurements taken at each time were averaged. Cultures that did not grow after 10 days at $40^{\circ} \mathrm{C}$ were moved to $22^{\circ} \mathrm{C}$, and 
colony diameters were measured after 4 days to determine whether the fungus would resume growth. Daily radial growth rates were calculated to give a final value. The colony morphology also was noted. The experiment was conducted twice.

Pathogenicity tests. Eight isolates of Alternaria spp. (A. alternata: X1020, X1265; A. arborescens: X100, X1033; A. tenuissima: X1026, X1259; A. infectoria: X1273; and A. rosae: $\mathrm{X} 1272$ ) recovered from decayed blueberry fruit were used in the pathogenicity tests. Conidia of tested isolates produced on 7-dayold PCA cultures incubated at $22^{\circ} \mathrm{C}$ under $8 \mathrm{~h}$ fluorescent light $/ 16 \mathrm{~h}$ dark were used to make conidial suspensions. Conidia were collected by scraping them off the surface of the medium with a sterile scalpel and placing them in a test tube with sterile water to make the conidial suspensions, which were then filtered through four layers of gauze. Concentrations of the spore suspensions were estimated using a hemocytometer and adjusted to $1 \times 10^{6}$ conidia per ml.

Freshly harvested organic 'Snow Chaser' blueberry fruit were obtained from a local blueberry farm and used for pathogenicity tests. The fruit were organically produced avoiding potential interference by fungicide residues on/in the fruit. The fruit were surface-disinfested in $0.5 \% \mathrm{NaOCl}(10 \%$ bleach) for $2 \mathrm{~min}$, rinsed three times with sterile distilled water and then air-dried. Fruit were wounded with a sterile needle to a depth of $2 \mathrm{~mm}$. Each fruit was inoculated by placing $1 \mu \mathrm{l}$ of conidial suspension with a pipette into the wound of each fruit. Inoculated fruit were placed on

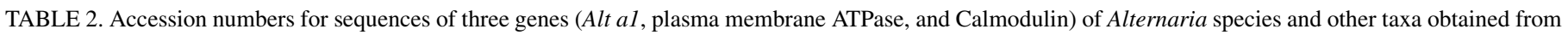
the GenBank used for comparison in the phylogenetic analysis

\begin{tabular}{|c|c|c|c|c|}
\hline \multirow[b]{2}{*}{ Name in GenBank } & \multirow[b]{2}{*}{ Isolate number ${ }^{y}$} & \multicolumn{3}{|c|}{ Accession number } \\
\hline & & Alt al & Plasma membrane ATPase & Calmodulin \\
\hline Alternaria alternata & EGS $34-016^{\mathrm{tab}}$ & AY563301 & JQ671874 & JQ646208 \\
\hline A. alternata & CBS 117130 & FN689396 & $\mathrm{N} / \mathrm{A}^{\mathrm{z}}$ & N/A \\
\hline A. alternata & CBS 117143 & FN689397 & N/A & N/A \\
\hline A. angustiovoidea & EGS $36-172^{\text {ta }}$ & JQ646398 & JQ671869 & JQ646203 \\
\hline A. arborescens & EGS $39-128^{\text {tab }}$ & AY563303 & JQ671880 & JQ646214 \\
\hline A. arborescens & MAP 05 & FN689414 & N/A & N/A \\
\hline A. arborescens & CBS 109730 & FN689398 & N/A & N/A \\
\hline A. arborescens & BMP 0602 & N/A & JQ811991 & N/A \\
\hline A. arborescens & BMP 0462 & N/A & JQ811990 & N/A \\
\hline A. argyroxiphii & EGS $35-122^{\text {ta }}$ & JQ646434 & JQ671926 & JQ646260 \\
\hline A. bursii & CBS $107.38^{\mathrm{a}}$ & JQ646388 & JQ671860 & N/A \\
\hline A. cerealis & EGS $43-072^{\text {ta }}$ & JQ646405 & JQ671883 & JQ646217 \\
\hline A. citri & CBS 192.81 & FN689399 & N/A & N/A \\
\hline A. citriarbusti & SH-MIL-8s ${ }^{a}$ & JQ646406 & JQ671884 & JQ646218 \\
\hline A. citrimacularis & BC2-RLR-17s $\mathrm{s}^{\mathrm{a}}$ & JQ646407 & JQ671885 & JQ646219 \\
\hline A. colombiana & BMP $2337^{a}$ & JQ646409 & JQ671887 & JQ646221 \\
\hline A. destruens & EGS $46-069^{\text {ta }}$ & JQ646402 & JQ671873 & JQ646207 \\
\hline A. dumosa & EGS $45-007^{\text {ta }}$ & N/A & JQ671877 & JQ646211 \\
\hline A. gaisen & CBS 632.93 & FN689401 & N/A & N/A \\
\hline A. gaisen & BMP $0243^{a}$ & JQ646400 & JQ671871 & JQ646205 \\
\hline A. herbiphorbicola & EGS $40-140^{\text {ta }}$ & JQ646410 & JQ671888 & JQ646222 \\
\hline A. hordeicola & EGS $50-184^{\mathrm{ta}}$ & JQ646372 & JQ671812 & JQ646146 \\
\hline A. infectoria & EGS $27-193^{\mathrm{tab}}$ & FJ266502 & JQ671804 & JQ646138 \\
\hline A. infectoria & MAP 03 & FN689415 & N/A & N/A \\
\hline A. infectoria & CBS 210.86 & FN689402 & N/A & N/A \\
\hline A. limoniasperae & EGS $45-100^{\text {tab }}$ & N/A & JQ671879 & JQ646213 \\
\hline A. longipes & EGS $30-033^{\mathrm{ab}}$ & AY563304 & JQ671864 & JQ646198 \\
\hline A. longipes & CBS 917.96 & FN689403 & N/A & N/A \\
\hline A. macrospora & DGG Ams $1^{\mathrm{a}}$ & N/A & JQ671909 & JQ646243 \\
\hline A. marlvae & CBS $447.86^{\mathrm{a}}$ & JQ646397 & JQ671878 & JQ646212 \\
\hline A. rosae & EGS $41-130^{\text {ta }}$ & JQ646370 & JQ671803 & JQ646137 \\
\hline A. septorioides (A. resedae) & CBS $175.80^{\mathrm{a}}$ & JQ646408 & JQ671886 & JQ646220 \\
\hline A. solani & ATCC $58177^{\mathrm{a}}$ & AY563299 & JQ671898 & JQ646232 \\
\hline A. steviae & CBS $632.88^{\mathrm{a}}$ & JQ646423 & JQ671906 & JQ646240 \\
\hline A. tangelonis & EV-MIL-2s ${ }^{\mathrm{a}}$ & JQ646392 & JQ671865 & JQ646199 \\
\hline A. tenuissima & BMP 0517 & N/A & JQ811982 & N/A \\
\hline A. tenuissima & BMP 1153 & N/A & JQ811985 & N/A \\
\hline A. tenuissima & BMP 0238 & N/A & JQ811984 & N/A \\
\hline A. tenuissima & BMP 0508 & N/A & JQ811987 & N/A \\
\hline A. tenuissima & BMP 1098 & N/A & JQ811986 & N/A \\
\hline A. tenuissima & BMP 1254 & N/A & JQ811988 & N/A \\
\hline A. tenuissima & MAP 01 & FN689408 & N/A & N/A \\
\hline A. tenuissima & CBS 880.95 & FN689407 & N/A & N/A \\
\hline A. tenuissima & EGS $34-015^{\text {tab }}$ & AY563302 & JQ671875 & JQ646209 \\
\hline A. tenuissima & BRIP 48081 & JQ282277 & N/A & N/A \\
\hline A. tomatophila & CBS $109156^{\mathrm{a}}$ & JQ646431 & JQ671923 & JQ646257 \\
\hline A. toxicogenica & PR $320^{\mathrm{a}}$ & JQ646411 & JQ671889 & JQ646223 \\
\hline A. tropica & CBS $631.93^{\mathrm{a}}$ & JQ646438 & JQ671930 & JQ646264 \\
\hline A. turkisafria & EGS 44-159a & JQ646404 & EF504051 & JQ646216 \\
\hline A. perangusta & BMP $2336^{\mathrm{a}}$ & JQ646403 & JQ671881 & JQ646215 \\
\hline Embellisia proteae & EGS $39-031^{\mathrm{a}}$ & FJ266505 & JQ671777 & JQ646111 \\
\hline Ulocladium chartarum & ATCC $18044^{\mathrm{a}}$ & AY563319 & JQ671828 & JQ646162 \\
\hline U. cucurbitae & EGS $31-021^{\mathrm{a}}$ & AY563315 & JQ671836 & JQ646170 \\
\hline U. dauci & CBS $102062^{a}$ & FJ266510 & JQ671832 & JQ646166 \\
\hline
\end{tabular}

${ }^{y} \mathrm{t}=$ ex-type isolate, $\mathrm{a}=$ isolate also included in Lawrence et al. (2013), and b = isolate also included in Woudenberg et al. (2013).

$\mathrm{z}$ N/A = not available. 
double-sided sticky tapes in the petri dishes and plates were kept in plastic boxes with a shallow depth of sterile water (about $0.5 \mathrm{~cm}$ ) on the bottom to keep high humidity. The plastic boxes were placed in incubators with designated temperatures at 0,4 or $20^{\circ} \mathrm{C}$ (commercially blueberries are commonly stored at 0 to $1^{\circ} \mathrm{C}$ ). Three 10-blueberry fruit replicates were inoculated with each isolate of the fungus for each temperature. For a control treatment, fruit were wounded as described above and treated with $1 \mu \mathrm{l}$ of sterile water instead of the conidial suspension. Fruit rot development was evaluated after incubation for 6 days at $20^{\circ} \mathrm{C}, 5$ weeks at $4^{\circ} \mathrm{C}$, and 3 additional days at room temperature after removal from 6-week storage at $0^{\circ} \mathrm{C}$. As blueberry fruit are small and difficult to measure the size of decay lesion on the fruit, for ease of assessment, severity of decay, expressed as percentage of the fruit surface decayed, was estimated for each fruit using the following scale: $0=$ no decay; $1=$ $\leq 1 / 8$ of the fruit surface decayed; $2=1 / 8$ to $1 / 4$ of the fruit surface decayed; $3=1 / 4$ to $1 / 2$ of the fruit surface decayed; $4=1 / 2$ to $3 / 4$ of the fruit surface decayed; and $5=\geq 3 / 4$ of the fruit surface decayed. The incidence of decay expressed as the percentage of the inoculated fruit that developed decay in each replicate was calculated. Reisolation of fungi from the decayed fruit was attempted. The experiment was conducted twice. Decay incidence and severity were analyzed by analysis of variance (ANOVA) performed using PROC ANOVA in SAS (version 9.3, SAS Institute, Cary, NC) with mean separation using Fisher's protected least significance test with $P=0.05$. Decay incidence data in percentage were arcsine-squareroot-transformed prior to analysis.

\section{RESULTS}

Phylogenetic analysis. The initial analysis of the partial sequences of the plasma membrane ATPase gene of the 283 Alternaria spp. isolates obtained from blueberry revealed a total of five groups. Compared with the sequences of the reference isolates and the ex-type or authentic representative isolates from the NCBI nucleotide database by the BLAST search, analysis of these five groups suggested that they belonged to five species: A. alternata, A. tenuissima, A. arborescens, A. infectoria, and A. rosae, respectively. Of the isolates sequenced for the plasma membrane ATPase gene, 35 representing the five groups (species) and covering all the sampled counties, along with eight reference Alternaria isolates from pistachio and some sequences of Alternaria spp. downloaded from GenBank (Table 2), were selected for further multilocus analysis comprising of plasma membrane ATPase, Calmodulin, and Alt al genes. Sequences of Alternaria spp. used in this study were deposited in GenBank (Table 1). Sequences of the plasma membrane ATPase gene of the Alternaria species ranged from 1,195 to 1,225 bp in which there were eight base pair differences between A. alternata and A. tenuissima and nine base pair differences between A. arborescens and $A$. alternata/A. tenuissima. Sequences of the Calmodulin gene ranged from 676 to $796 \mathrm{bp}$ in which there were six base pair differences between $A$. arborescens and A. alternatalA. tenuissima. Sequences of the Alt al gene ranged from 431 to $473 \mathrm{bp}$. The aligned sequences of each dataset of plasma membrane ATPase (85 taxa, 1,201 characters), Calmodulin (76 taxa, 756 characters), and Alt al (86 taxa, 353 characters) gene regions were deposited in TreeBASE (http://www.treebase.org).

In the parsimony analysis, statistical data for the plasma membrane ATPase gene were as follows: tree length for MP = 493, consistency index $(C I)=0.7525$, retention index $(\mathrm{RI})=0.9196$, rescaled consistency index $(\mathrm{RC})=0.6920$, homoplasy index $(\mathrm{HI})=$ 0.3020; for Calmodulin: tree length $=447, \mathrm{CI}=0.7673, \mathrm{RI}=0.9404$, $\mathrm{RC}=0.7216, \mathrm{HI}=0.2613$; for Alt al $:$ tree length $=303, \mathrm{CI}=0.7228$, $\mathrm{RI}=0.9190, \mathrm{RC}=0.6642, \mathrm{HI}=0.3387$; and for the three-gene combined sequences: tree length $=1,247, \mathrm{CI}=0.7193, \mathrm{RI}=0.9098$, $\mathrm{RC}=0.6544, \mathrm{HI}=0.3265$. For Bayesian analysis, model test analysis recommended appropriate models as follows: GTR+G model $\left(\right.$ Lset base $=\left[\begin{array}{llll}0.2162 & 0.3089 & 0.2523 & 0.2226\end{array}\right]$; Nst $=6$;
Rmat $=\left[\begin{array}{l}1.80693 .33511 .90431 .81987 .7586\end{array}\right]$; rates = gamma; shape $=$ 0.2163; pinvar $=0$ ) for the plasma membrane ATPase gene region, a TIM+G model $\left(\right.$ Lset base $=\left[\begin{array}{lllll}0.2381 & 0.3539 & 0.2339 & 0.1741\end{array}\right] ;$ Nst = 6;

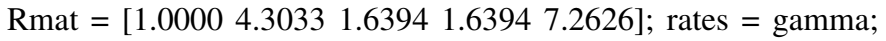
shape $=0.3751 ;$ pinvar $=0$ ) for the Calmodulin gene region, $\mathrm{a}$

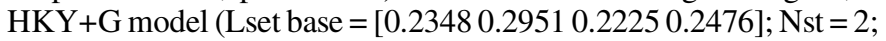
Tratio $=1.7759$; rates $=$ gamma; shape $=0.6253$; pinvar $=0$ ) for the Alt al gene region, and a $\mathrm{TrN}+\mathrm{I}+\mathrm{G}$ model (Lset base $=[0.2294$ $0.32250 .24320 .2050]$; Nst $=6$; Rmat $=\left[\begin{array}{lll}1.0000 & 2.64641 .0000\end{array}\right.$ 1.0000 5.3196]; rates = gamma; shape $=1.0929$; pinvar $=0.4612$ ) for the combined sequences of the three gene regions. For all the three gene regions and their combination, topologies of their trees were basically similar in the maximum parsimony and Bayesian inference. Four phylogenetic trees reconstructed from parsimony bootstrap values and posterior probabilities are presented in Figures 1 to 4 .

The phylogenetic analysis for the plasma membrane ATPase gene showed that the 35 isolates from blueberry could be divided into five groups: 14 isolates were clustered in the same group with the reference isolates of $A$. alternata by high bootstrap value of $97 / 1.00$, nine isolates were clustered in the same group with the reference isolates of $A$. tenuissima by high bootstrap value of 95/1.00, 10 isolates were clustered in the same group with the reference isolates of $A$. arborescens by high bootstrap value of $100 / 1.00$, one isolate X1273 was clustered in the same group with the reference isolates of $A$. infectoria by high bootstrap value of $99 / 0.98$, and one isolate X1272 was clustered in the same group with the reference sequence of $A$. rosae from GenBank, which were supported by high MP bootstrap support of 80/0.99 (Fig. 1).

Compared with the reference isolates, the phylogenetic analysis of Calmodulin gene differentiated $A$. arborescens, $A$. infectoria, and A. rosae from other Alternaria spp. supported by a high bootstrap value; however, A. alternata and A. tenuissima were grouped in the same cluster (Fig. 2). The phylogenetic analysis of Alt al gene differentiated $A$. infectoria and A. rosae from others (Fig. 3). Although reference isolates 03.J24 and 03.J29 of A. arborescens were grouped in one cluster, the MP bootstrap support was lower than 70, which was believed not to be reliable (Fig. 3). Similarly A. alternata and A. tenuissima were clustered in the same groups (Fig. 3). In the phylogenetic analysis of combined sequences of plasma membrane ATPase, Calmodulin and Alt al genes, A. infectoria and $A$. rosae could be differentiated by high MP bootstrap supports. A. arborescens isolates were grouped in one cluster, but both A. alternata and A. tenuissima isolates were clustered into the same groups (Fig. 4).

Morphological characteristics of cultures and sporulation. In total, 17 isolates representing five species of Alternaria identified based on the sequences of the three gene regions were used for morphological observations (Table 1). Based on the colony morphology, colony growth, and sporulation patterns, these Alternaria isolates were grouped in five distinct groups as described below.

The isolates in group A and group B developed colonies that were lettuce green to olive green and usually had a prominent white margin. Colony texture was felty to woolly, and $46 \%$ of the isolates in these two groups produced whitish crystals in the agar medium underneath the mycelial mat (Fig. 5). Isolates in group A developed conidial chains of 6 to 15 conidia in length and the secondary chains of 1 to 6 conidia in length. Conidia chain branched in a sympodial manner by the elongation of secondary conidiophores from distal terminal conidial cells or through the lateral growth of secondary conidiophores from median or basal conidial cells and subsequently formed conidia. Conidia were typically ovate to obclavate in shape. Those isolates were identified as A. alternata, which grew at $9.1 \mathrm{~mm}$ per day at $22^{\circ} \mathrm{C}$ and the conidia size was 14.6 to $36.2 \times 5.2$ to $15.0 \mu \mathrm{m}$ (Table 3). The isolates in group B developed conidial chains of 6 to 18 conidia in length and the uncommon secondary chains of 1 to 4 conidia in length. Conidial chains typically branched by the lateral growth of secondary conidiophores from 
distal terminal conidial cells and subsequently formed conidia. Conidia were typically ovate to obclavate in shape. These isolates were identified as A. tenuissima, which grew $9.8 \mathrm{~mm}$ per day at $22^{\circ} \mathrm{C}$ (Table 3$)$. The conidia size of $A$. tenuissima $(13.9$ to $43.0 \times 5.8$ to $13.7 \mu \mathrm{m})$ is similar to that of A. alternata.

Isolates in group $\mathrm{C}$ were $A$. arborescens. The colonies were typically dark olive gray, iron gray to castor gray in color. The colony margin was generally wavy or torn (Fig. 5) and $98 \%$ of the isolates in this group produced a diffusible pale orange pigment and abundant crystals in the agar medium underneath the mycelial mat. Colony grew slower than other species $(4.7 \mathrm{~mm}$ per day between 3 to 5 days incubation at $22^{\circ} \mathrm{C}$ ) (Fig. 5, Table 3). The isolates in this group formed conidial chains of two to six (occasionally 8 ) conidia in length and produced numerous secondary, tertiary, and quaternary chains of two to four conidia in length. Chain branching typically occurred in a sympodial manner by the elongation of secondary conidiophores from distal terminal conidial cells and subsequently formed conidia. Some isolates generally formed long

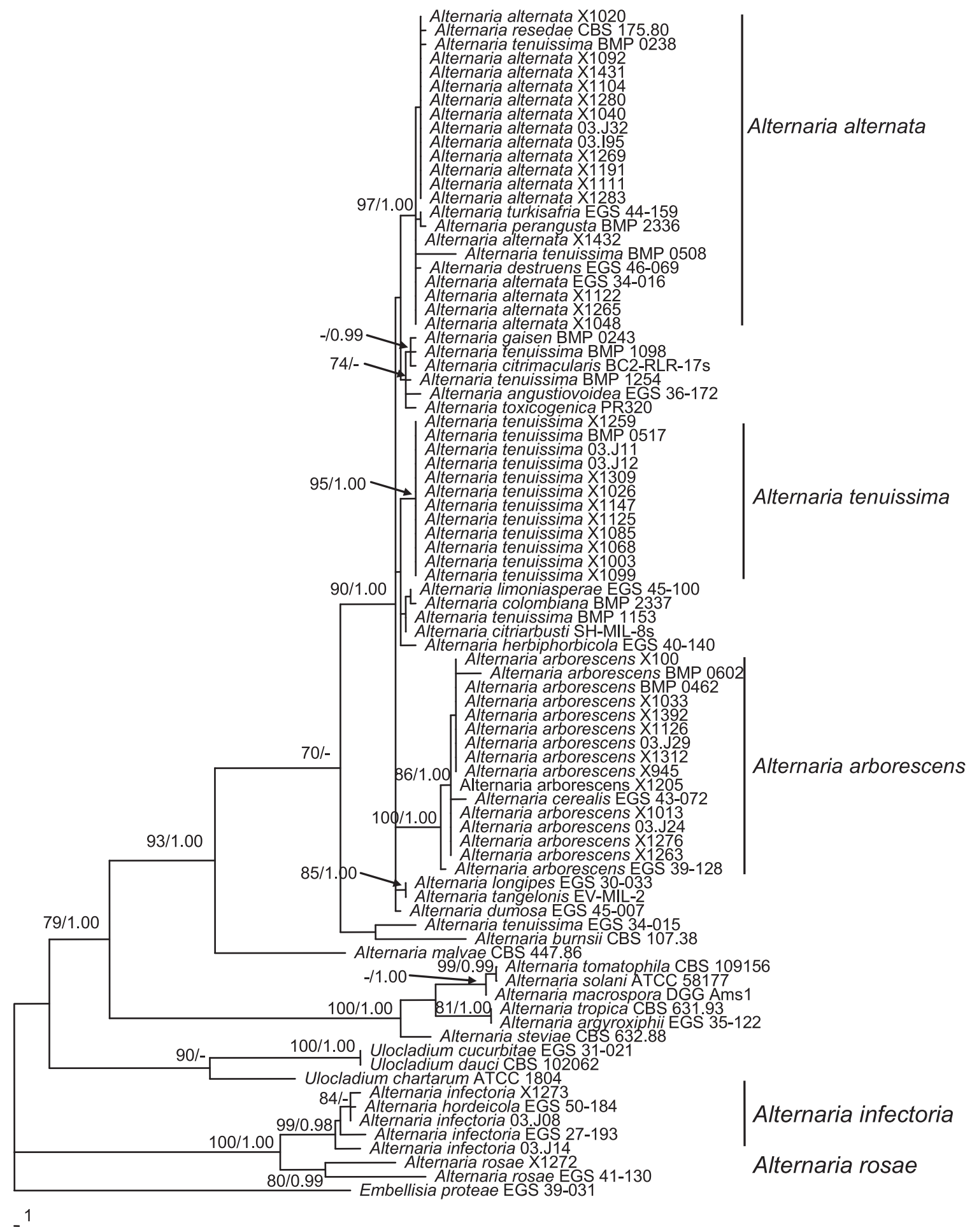

Fig. 1. Phylogenetic trees inferred from the plasma membrane ATPase gene sequences from maximum parsimony (MP) and Bayesian analysis for Alternaria spp. from blueberry and reference isolates of Alternaria spp. Embellisia proteae (EGS 39-031) was selected as outgroup. Isolates beginning with X were collected from blueberry in California and all other isolates used in the phylogenetic analyses are listed in Tables 1 and 2. Bootstrap support values (1,000 replicates) above 70\% for MP and above 0.95 for Bayesian analysis are shown. Species are followed by strain numbers. 
primary conidiophores and then had the initiation of conidial chains. Conidia were typically ovate in shape $(11.7$ to $35.3 \times 6.3$ to $15.0 \mu \mathrm{m})$ (Table 3).

The isolates in group D belonged to A. infectoria. The colony was apricot orange in color. The colony generally had a cottony texture and tufts of sterile white hyphae were present at the center of the colony (Fig. 5). It produced an orange pigmentation without crystals. Colony growth rate was $10.2 \mathrm{~mm}$ per day at $22^{\circ} \mathrm{C}$ (Table 3 ). Isolates in this group formed conidial chains of two to eight conidia in length and developed numerous secondary, tertiary, and quaternary chains of two to four conidia in length. Chain branched typically in sympodial manner. Secondary conidiophores were generally one to three times the length of conidia. Conidia (12.9 to $25.5 \times 5.3$ to $10.9 \mu \mathrm{m}$ ) were typically ovate to obclavate in shape (Fig. 5, Table 3). Some conidia developed distinctive apical extensions in no less than the length of the conidium body.

In group $\mathrm{E}$, isolates produced colonies lettuce green in color and had a prominent white margin with about 15 to $20 \mathrm{~mm}$ in width

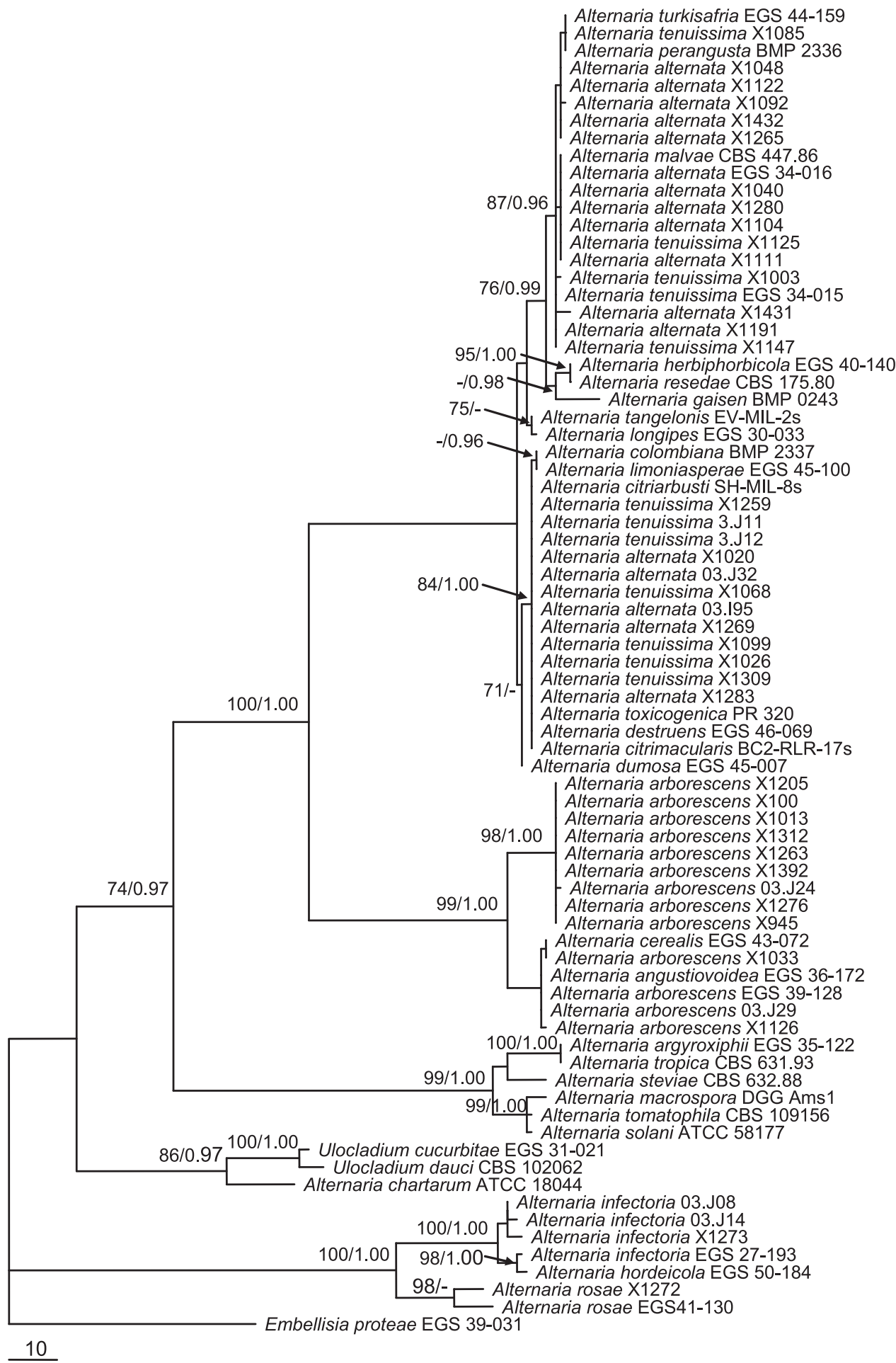

Fig. 2. Phylogenetic trees inferred from maximum parsimony (MP) and Bayesian analysis of Calmodulin gene sequences for Alternaria spp. from blueberry and reference isolates of Alternaria spp. Embellisia proteae (EGS 39-031) was selected as outgroup. Isolates beginning with X were collected from blueberry in California and all other isolates used in the phylogenetic analyses are listed in Tables 1 and 2. Bootstrap support values (1,000 replicates) above 70\% for MP and above 0.95 for Bayesian analysis are shown. Species are followed by strain numbers. 
(Fig. 5, Table 3). The colony growth of this fungus was about $11.1 \mathrm{~mm}$ per day at $22^{\circ} \mathrm{C}$ (Table 3 ). Primary conidiophores in granular clumps under the dissecting microscope, simple or branched, arose in close proximity from hyphae and with a short conidial chain of one to seven conidia in length formed on the conidiogenous site at each geniculate extension or tip of the conidiophores. Conidia (10.1 to $24.6 \times 4.7$ to $8.9 \mu \mathrm{m}$ ) were ovoid or elliptical (Table 3, Fig. 5). One isolate X1272 with those characteristics was identified as A. rosae.
Species distribution of Alternaria spp. Of the 283 Alternaria isolates obtained from blueberries, $61.5 \%$ were identified as A. alternata, $32.9 \%$ were $A$. arborescens, $5.0 \%$ were A. tenuissima, and only one isolate of $A$. infectoria and one isolate of A. rosae were found. A. alternata and A. arborescens were present at all five sampled locations. A. tenuissima was present at two locations (Kingsburg and Delano). A. infectoria and A. rosae were found only in Tulare (Table 1).

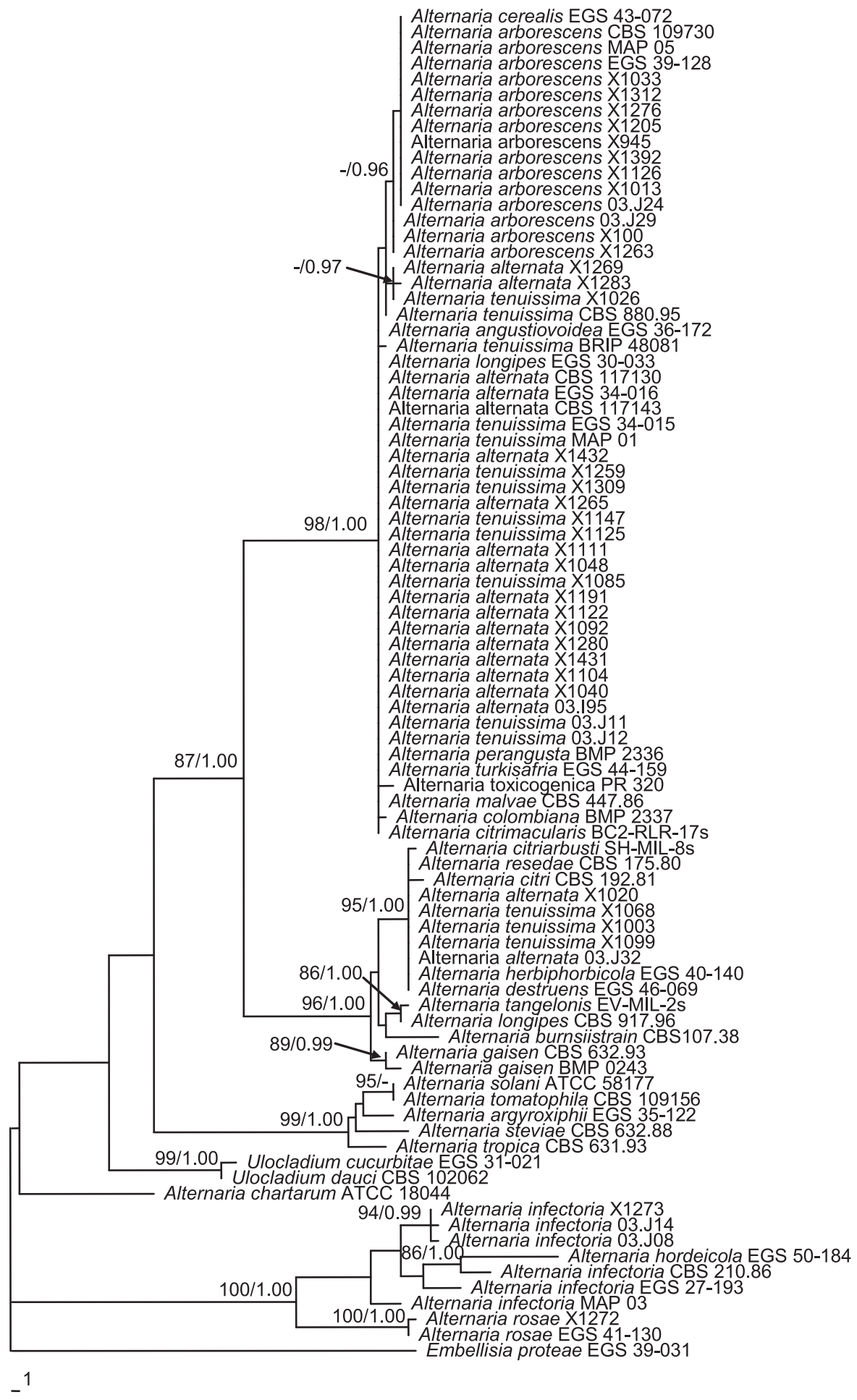

Fig. 3. Phylogenetic trees inferred from maximum parsimony (MP) and Bayesian analysis of Alt al gene sequences for Alternaria spp. from blueberry and reference isolates of Alternaria spp. Embellisia proteae (EGS 39-031) was selected as outgroup. Isolates beginning with X were collected from blueberry in California and all other isolates used in the phylogenetic analyses are listed in Tables 1 and 2. Bootstrap support values (1,000 replicates) above 70\% for MP and above 0.95 for Bayesian analysis are shown. Species are followed by strain numbers. 
Temperature response. The Alternaria isolates were able to grow at temperature from 0 to $35^{\circ} \mathrm{C}$ (Fig. 6). Radial growth rate increased with temperature up to 25 or $30^{\circ} \mathrm{C}$, and then decreased rapidly as temperature increased. Optimal radial growth occurred between 20 and $30^{\circ} \mathrm{C}$. The average radial growth of $A$. alternata, A. tenuissima, A arborescens, A. infectoria, and A. rosae was 8.7, 9.7, 9.0, 11.9, and $10.1 \mathrm{~mm}$ per day at $25^{\circ} \mathrm{C}$, respectively. At $40^{\circ} \mathrm{C}$, mycelial growth was arrested, but growth resumed when culture of A. infectoria and $A$. rosae isolates were incubated at $22^{\circ} \mathrm{C}$. However, after 10 days of incubation at $40^{\circ} \mathrm{C}$, all A. alternata, A. tenuissima, and $A$. arborescens isolates failed to resume growth after an additional 10 days of incubation at $22^{\circ} \mathrm{C}$ and were presumably dead.

Pathogenicity and virulence. ANOVA indicated that there were no significant differences between the results of the two experiments; therefore, the data were combined for further analyses. All inoculated fruit that were incubated at 4 and $20^{\circ} \mathrm{C}$ developed Alternaria rot symptoms, except $98 \%$ of the fruit inoculated with $A$. rosae and incubated at $20^{\circ} \mathrm{C}$ were decayed

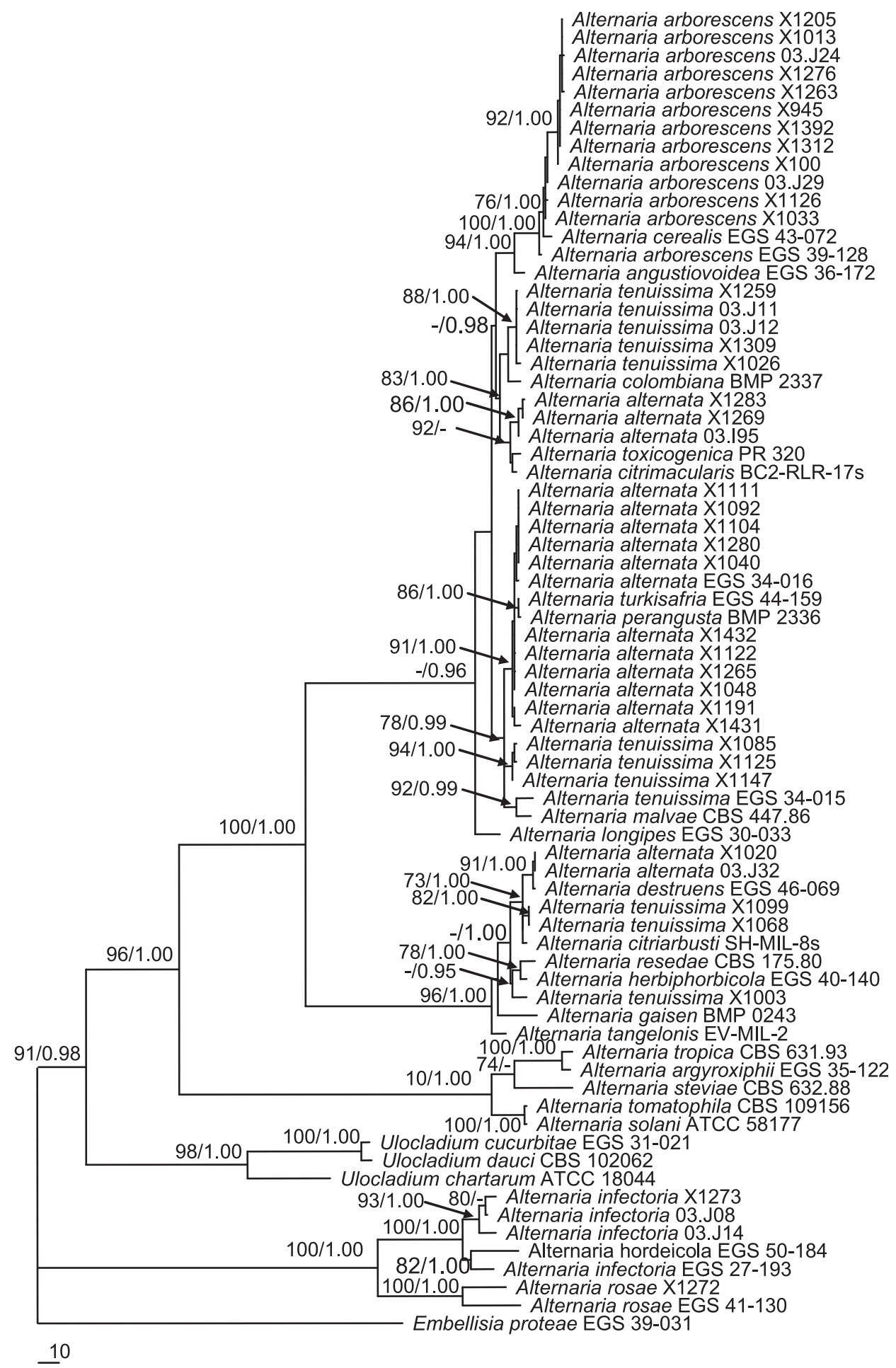

Fig. 4. Phylogenetic trees inferred maximum parsimony (MP) and Bayesian analysis of combined sequences of plasma membrane ATPase, Calmodulin and Alt al genes for Alternaria spp. from blueberry and reference isolates of Alternaria spp. Embellisia proteae (EGS 39-031) was selected as outgroup. Isolates beginning with X were collected from blueberry in California and all other isolates used in the phylogenetic analyses are listed in Tables 1 and 2. Bootstrap support values (1,000 replicates) above $70 \%$ for MP and above 0.95 for Bayesian analysis are shown. Species are followed by strain numbers. 
(Table 4). Decay developed slowly during the 6-week incubation at $0^{\circ} \mathrm{C}$, but the majority of the fruit developed decay symptoms after 3 additional days at $20^{\circ} \mathrm{C}$ after removal from $0{ }^{\circ} \mathrm{C}$ (Table 4). No decay developed on fruit in the control treatment, except $2 \%$ decay was observed in the control at $4{ }^{\circ} \mathrm{C}$ (Table 4). The original fungi were reisolated from decayed fruit that were inoculated with respective isolates. Under the same incubation conditions, differences in lesion sizes (disease severity) on the fruit were not significantly different on the fruit inoculated with isolates among the alternata, tenuissima, or arborescens species-group (Table 4). In contrast, average disease severity for the isolates of $A$. infectoria and $A$. rosae was 1.7 and 1.8 , respectively, which were significantly lower than those of isolates of A. alternata, A. tenuissima, and A. arborescens (Table 4).

\section{DISCUSSION}

This research presented the first study on the characterization of Alternaria spp. responsible for fruit rot of blueberry in California. Based on multiple DNA sequence comparisons and fungal morphological characteristics, we documented that five Alternaria species, including A. alternata, A. tenuissima, A. arborescens, $A$. infectoria, and A. rosae, are present in blueberry in California, and that A. alternata and $A$. arborescens are the dominant species present in all five sampling locations in the major blueberry production region in central California.

The species A. tenuissima has been reported to be the primary causal agent of Alternaria leaf spot and fruit rot in blueberry worldwide (Cline 1996; Greco et al. 2012; Milholland and Jones 1972; You et al. 2013), though A. alternata has also been reported to be associated with fruit rot of blueberry (Mehra et al. 2012). In our study, only $5 \%$ of the isolates were A. tenuissima, whereas 61.5 and $32.9 \%$ were $A$. alternata and $A$. arborescens, respectively. With the exception of $A$. tenuissima, A. alternata, A. arborescens, $A$. infectoria, and $A$. rosae are newly reported on blueberry in California. This is also the first report of A. infectoria and A. rosae causing Alternaria fruit rot on blueberry worldwide. Our results indicated that the species composition of Alternaria responsible for Alternaria fruit rot in blueberry can be dependent on geographical region. In the Central Valley of California which is the primary

TABLE 3. Conidia size and mycelial growth rate of Alternaria spp. from blueberry ${ }^{\mathrm{z}}$

\begin{tabular}{|c|c|c|c|c|c|}
\hline Species & Isolate & Length of conidia $(\mu \mathrm{m})$ & Width of conidia $(\mu \mathrm{m})$ & Length/width & $\begin{array}{c}\text { Growth rate at } 22^{\circ} \mathrm{C} \text { under } 8 \mathrm{~h} \text { light } / 16 \mathrm{~h} \\
\text { darkness }(\mathrm{mm} / \text { day })\end{array}$ \\
\hline Alternaria alternata & $\begin{array}{l}\text { X1020 } \\
\text { X1269 } \\
\text { X1048 } \\
\text { X1265 } \\
\text { X1432 } \\
\text { Mean }\end{array}$ & $\begin{array}{l}22.62 \pm 0.62(14.60-31.70) \\
20.69 \pm 0.47(15.20-28.5) \\
23.02 \pm 0.66(16.10-36.20) \\
22.89 \pm 0.53(16.80-30.60) \\
20.98 \pm 0.53(16.10-27.80) \\
22.04 \mathrm{a}\end{array}$ & $\begin{array}{l}7.92 \pm 0.17(5.20-10.50) \\
7.62 \pm 0.14(5.80- \\
9.58 \pm 0.22(7.20-14.40) \\
9.39 \pm 0.28(6.40-15.00) \\
8.99 \pm 0.25(6.70-14.60) \\
8.70 \mathrm{ab}\end{array}$ & $\begin{array}{l}2.88 \pm 0.07(2.00-4.00) \\
2.74 \pm 0.07(1.80-4.50) \\
2.46 \pm 0.09(1.60-4.10) \\
2.54 \pm 0.10(1.30-4.60) \\
2.40 \pm 0.07(1.50-3.60) \\
2.60 \mathrm{a}\end{array}$ & $\begin{array}{l}9.7 \pm 0.20(9.40-10.70) \mathrm{bc} \\
7.80 \pm 0.64(6.70-8.50) \mathrm{de} \\
9.70 \pm 0.91(8.60-10.90) \mathrm{bc} \\
7.90 \pm 0.37(6.70-9.00) \mathrm{de} \\
10.20 \pm 0.20(9.70-10.70) \mathrm{b} \\
9.06 \mathrm{~B}\end{array}$ \\
\hline A. tenuissima & $\begin{array}{l}\text { X1125 } \\
\text { X1068 } \\
\text { X1003 } \\
\text { X1259 } \\
\text { X1026 } \\
\text { Mean }\end{array}$ & $\begin{array}{l}22.02 \pm 0.32(13.90-36.60) \\
20.20 \pm 0.18(15.90-26.7) \\
21.74 \pm 0.24(15.00-30.30) \\
24.23 \pm 0.42(16.8-43.00) \\
22.82 \pm 0.23(15.30-32.20) \\
22.18 \mathrm{a}\end{array}$ & $\begin{aligned} 9.62 & \pm 0.12(7.00-13.70) \\
9.31 & \pm 0.12(5.80-13.2) \\
10.15 & \pm 0.13(6.50-4.20) \\
8.35 & \pm 0.08(5.80-10.40) \\
8.30 & \pm 0.07(6.00-10.60) \\
9.14 \mathrm{a} & \end{aligned}$ & $\begin{array}{l}2.35 \pm 0.04(1.30-3.60) \\
2.25 \pm 0.03(1.40-3.60) \\
2.19 \pm 0.03(1.60-3.50) \\
2.94 \pm 0.05(1.80-4.90) \\
2.78 \pm 0.03(1.90-4.40) \\
2.50 \mathrm{ab}\end{array}$ & $\begin{aligned} 9.50 & \pm 0.22(8.80-10.10) \mathrm{c} \\
9.90 & \pm 0.21(9.50-10.90) \mathrm{bc} \\
11.10 & \pm 0.38(10.00-12.30) \mathrm{a} \\
10.20 & \pm 0.21(9.70-10.90) \mathrm{b} \\
8.30 & \pm 0.15(8.00-8.90) \mathrm{d} \\
9.80 \mathrm{~B} & \end{aligned}$ \\
\hline A. arborescens & $\begin{array}{l}\text { X1276 } \\
\text { X1263 } \\
\text { X945 } \\
\text { X1033 } \\
\text { X100 } \\
\text { Mean }\end{array}$ & $\begin{array}{l}21.23 \pm 0.21(16.20-28.50) \\
19.43 \pm 0.23(13.50-28.50) \\
16.21 \pm 0.19(11.70-27.70) \\
24.31 \pm 0.30(15.90-35.30) \\
23.74 \pm 0.31(14.90-33.40) \\
20.96 \mathrm{ab}\end{array}$ & $\begin{array}{l}9.84 \pm 0.13(6.60-14.40) \\
9.15 \pm 0.11(6.90-15.00) \\
7.84 \pm 0.05(6.40-9.70) \\
9.00 \pm 0.09(6.60-12.20) \\
8.92 \pm 0.09(6.30-12.10) \\
8.92 \mathrm{a}\end{array}$ & $\begin{array}{l}2.16 \pm 0.03(1.2-4.00) \\
2.16 \pm 0.03(1.50-3.10) \\
2.08 \pm 0.03(1.40-4.30) \\
2.75 \pm 0.04(1.70-5.10) \\
2.72 \pm 0.04(1.60-4.50) \\
2.40 \mathrm{ab}\end{array}$ & $\begin{array}{l}3.40 \pm 0.36(2.00-4.40) \mathrm{g} \\
5.00 \pm 0.45(4.30-5.90) \mathrm{f} \\
2.7 \pm 0.47(1.20-4.50) \mathrm{h} \\
7.50 \pm 0.41(6.30-9.10) \mathrm{e} \\
5.00 \pm 0.29(4.10-6.00) \mathrm{f} \\
4.72 \mathrm{C}\end{array}$ \\
\hline A. infectoria & $\begin{array}{l}\text { X1273 } \\
\text { Mean }\end{array}$ & $\begin{array}{l}19.12 \pm 1.33(12.90-25.50) \\
19.12 \mathrm{~b}\end{array}$ & $\begin{array}{l}7.76 \pm 0.61(5.30-10.90) \\
7.76 \mathrm{bc}\end{array}$ & $\begin{array}{l}2.54 \pm 0.27(1.60-3.90) \\
2.54 \mathrm{a}\end{array}$ & $\begin{array}{l}10.20 \pm 0.28(9.30-11.00) \mathrm{b} \\
10.20 \mathrm{AB}\end{array}$ \\
\hline A. rosae & $\begin{array}{l}\text { X1272 } \\
\text { Mean }\end{array}$ & $\begin{array}{l}13.94 \pm 1.41(10.10-24.60) \\
13.94 \mathrm{c}\end{array}$ & $\begin{array}{l}6.82 \pm 0.41(4.70-8.90) \\
6.82 \mathrm{c}\end{array}$ & $\begin{array}{l}2.07 \pm 0.22(1.40-3.60) \\
2.07 \mathrm{~b}\end{array}$ & $\begin{array}{l}11.10 \pm 0.31(10.10-11.90) \mathrm{a} \\
11.10 \mathrm{~A}\end{array}$ \\
\hline
\end{tabular}

$\mathrm{z}$ Values are average \pm standard error (minimum-maximum), and values followed by the same letter within the same column are not significantly different $(P=$ 0.05). Only means are compared for length, width, and length/width ratio among the species groups.

TABLE 4. Incidence $(\%)$ and severity of Alternaria rot on blueberry fruit inoculated with different Alternaria spp. ${ }^{\mathrm{z}}$

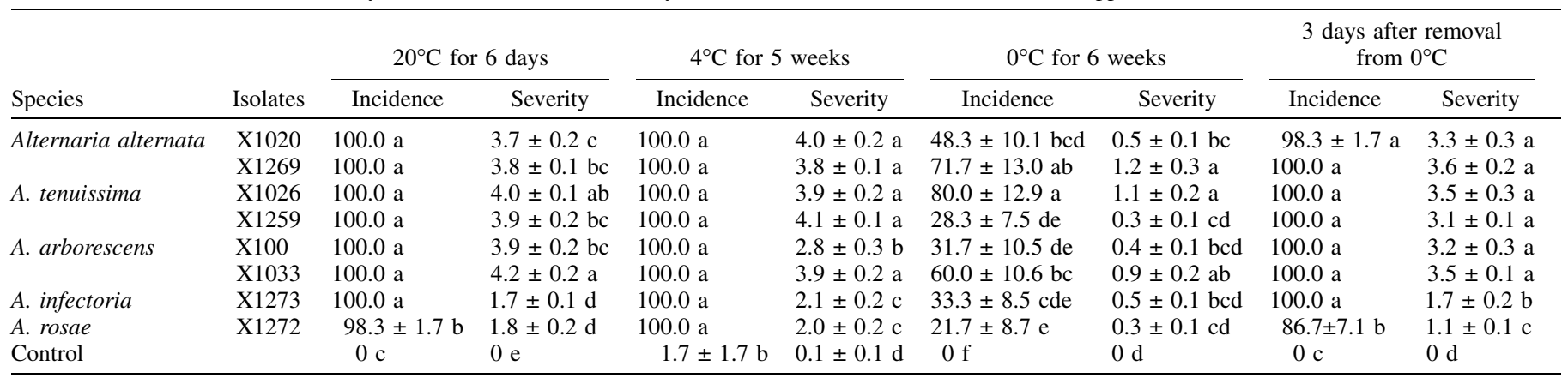

${ }^{\mathrm{z}}$ Severity was based on the lesion development on inoculated blueberry fruit using the following scale: 0 , no decay; 1 , lesion $\leq 12.5 \% ; 2,12.5 \%<$ lesion $\leq 25 \% ; 3$, $25 \%<$ lesion $\leq 50 \% ; 4,50 \%<$ lesion $\leq 75 \%$; and $5,75 \%<$ lesion $\leq 100 \%$. Values followed by the same letter within the same column are not significantly different $(P=0.05)$. 
region for production of a wide range of fruit and nut crops such as almond, citrus, and pistachio, blueberries are commonly grown in fields in close proximity to those crops. A. alternata is the cause of Alternaria leaf spot of almond and Alternaria late blight of pistachio, and A. arborescens and A. tenuissima have also been reported on these crops in the region (Pryor and Michailides 2002; Teviotdale and Adaskaveg 2002). The similarity in Alternaria species composition between blueberry and the nut crops (pistachio and almond) in the region may suggest that these nut crops may be an important source of Alternaria inoculum contributing to the
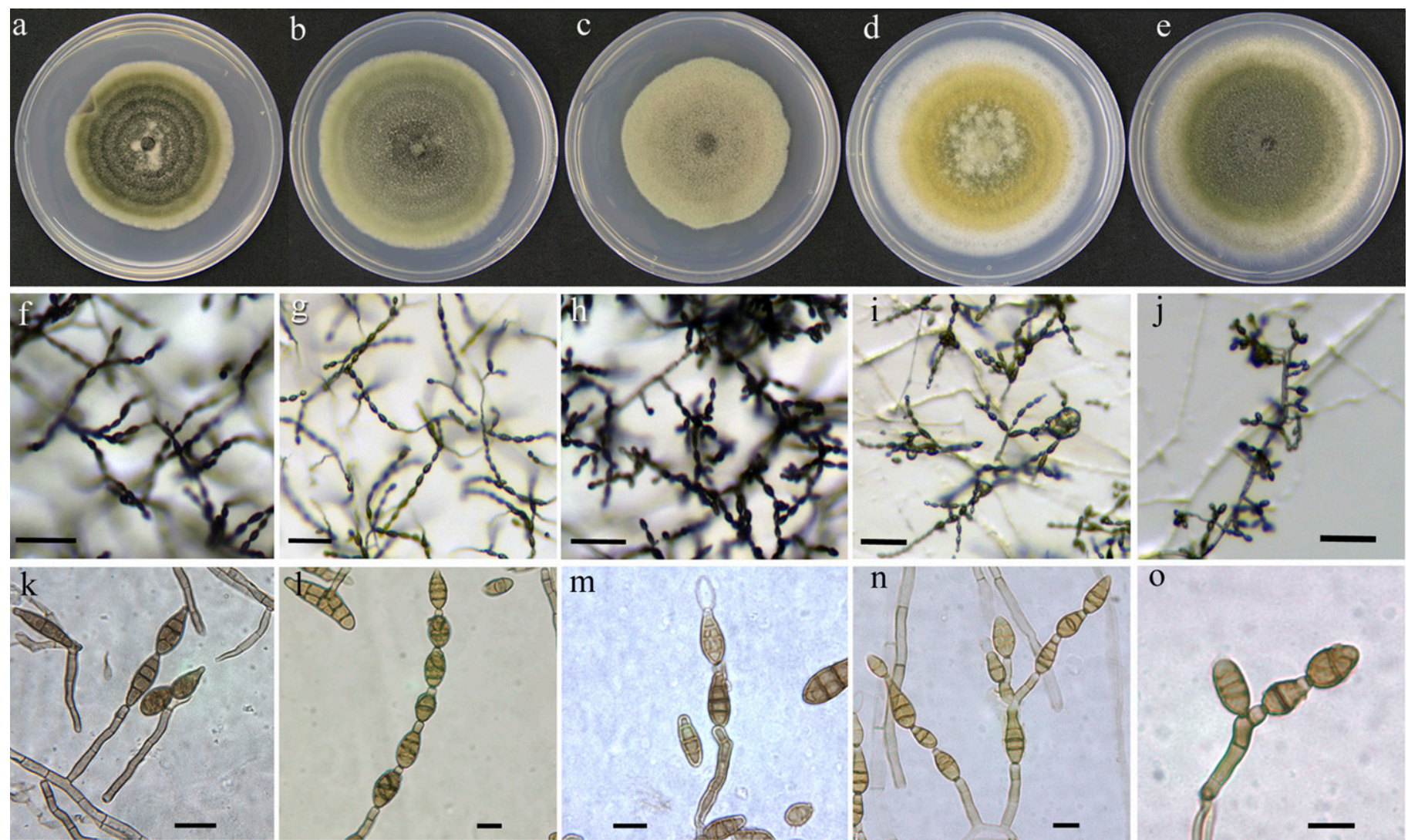

$\mathrm{m}$

Fig. 5. Morphological features of Alternaria spp. isolated from blueberry. a to e, Colony morphology on potato dextrose agar after 7 days under cool white fluorescent light with an $8 \mathrm{~h}$ photoperiod and $16 \mathrm{~h}$ darkness; $\mathbf{f}$ to o, sporulation pattern on potato carrot agar after 7 days under cool white fluorescent light with an $8 \mathrm{~h}$ photoperiod and $16 \mathrm{~h}$ darkness; a, f, and $\mathbf{k}$, A. alternata isolate X1020; b, g, and $\mathbf{i}$, A. tenuissima isolate X1259; c, h, and m, A. arborescens isolate X1033; $\mathbf{d}, \mathbf{i}$, and $\mathbf{n}$, A. infectoria isolate X1273; and $\mathbf{e}, \mathbf{j}$, and $\mathbf{o}, A$. rosae isolate X1272. Scale bar of $\mathrm{f}$ to $\mathrm{j}=0.05 \mathrm{~mm}$; scale bar of $\mathrm{k}$ to $\mathrm{o}=10 \mu \mathrm{m}$.

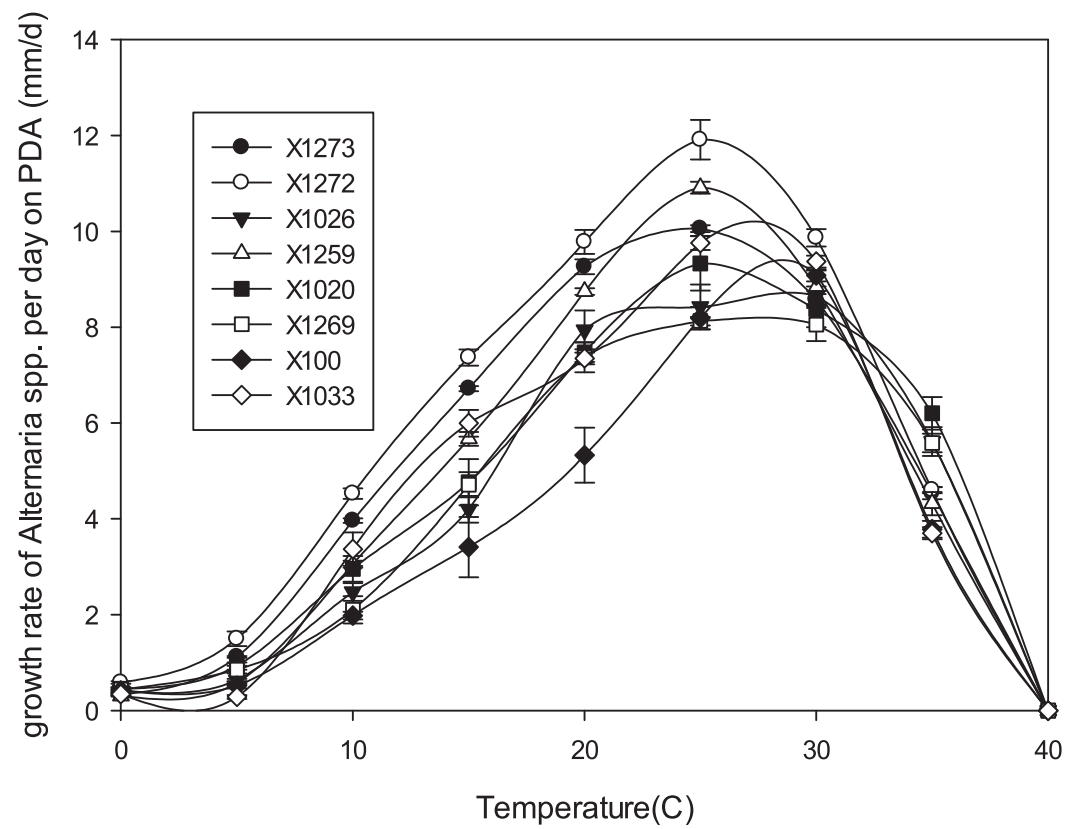

Fig. 6. Effect of temperature on radial mycelial growth rate (mm/day) of Alternaria alternata (X1269, X1020), A. arborescens (X100, X1033), A. tenuissima (X1026, X1259), A. infectoria (X1273), and A. rosae (X1272) on potato dextrose agar in the dark. Values are the means of pooled data from the two runs of the experiment. 
establishment of Alternaria spp. population in blueberry in California as blueberry is a relatively new crop in the region compared with these nut crops (Jimenez et al. 2005).

Previously, identification of Alternaria spp. associated with blueberry, pistachio, and other crops has been largely based on morphological characters such as colony and sporulation morphology (Cline 1996; Greco et al. 2012; Milholland and Jones 1972; Pryor and Michailides 2002; You et al. 2013). Recently, DNA sequence-based analysis offers an increasingly important tool for speciation of Alternaria, particularly small-spored species (Andrew et al. 2009; Deng et al. 2012; Greco et al. 2012; Hong et al. 2005; Jasnic et al. 2011; Lawrence et al. 2013; Luan et al. 2007; Woudenberg et al. 2013; You et al. 2013). Plasma membrane ATPase, Calmodulin, and Alt al genes were selected to identify Alternaria spp. in this study. All the isolates from blueberry in this study could be clearly distinguished from each other by analyzing the sequences of the plasma membrane ATPase gene. $A$. arborescens, $A$. infectoria, and $A$. rosae could also be differentiated by the sequences of Alt al or Calmodulin, except that A. alternata and A. tenuissima were still in the same group. Although small-spored Alternaria spp. in this study can be largely differentiated by DNA sequence, morphological characters are still important in differentiating some species. The phylogenetic analysis from the plasma membrane ATPase gene indicated that some species including $A$. resedae, A. turkisafria, A. perangusta, and $A$. destruens were clustered into the same group with A. alternata isolates from blueberry and the reference isolates of A. alternata, and those species could be differentiated from A. alternata by morphological characteristics. In addition, two isolates of A. tenuissima (BMP 0238 and BMP 0508) from GenBank were divided into the same group with A. alternata in this study and the reference isolates of A. alternata. Thus, the two isolates in the GenBank could be re-examined to verify their identity by morphological characters described by Simmons (2007). Of the several small-spored Alternaria spp. with morphological characteristics that overlap those of A. alternata, the most commonly known are A. tenuissima and A. infectoria, and the intermediate characteristics make them frequently misidentified as A. alternata (Roberts et al. 2000; Simmons and Roberts 1993). In the present study, colonies of A. alternata and A. tenuissima were similar, though the sporulation was usually different. Moreover, for those isolates without typical characteristics of A. alternata, A. tenuissima, and A. arborescens, they could not be distinguished easily. A. arborescens generally grew more slowly than other species, the margin of the colony often wavy and torn, the colors of colony were usually dark olive gray to castor gray. Moreover, sporulation of $A$. arborescens was distinct with numerous secondary to quaternary branching. Morphology and sporulation of $A$. infectoria and A. rosae were significantly different from those of the other species. Our results suggest that DNA sequence comparisons of multiple gene regions combined with morphological characteristics are important in speciation of Alternaria associated with blueberry.

Fruit inoculation studies showed that all five Alternaria species caused fruit rot on detached blueberry fruit stored at 0,4 , or $20^{\circ} \mathrm{C}$, indicating that these species were pathogenic to blueberry fruit and can cause fruit rot at the storage temperature of $0^{\circ} \mathrm{C}$. Although all five Alternaria spp. were pathogenic to blueberry fruit, the decay lesion sizes on the fruit inoculated with $A$. infectoria and A. rosae were significantly smaller than those on the fruit inoculated with A. alternata, A. tenuissima, or A. arborescens, suggesting that $A$. infectoria and $A$. rosae were less virulent to blueberry fruit than the other Alternaria species tested in this study. Similar observations have also been reported by Pryor and Michailides (2002) who documented that $A$. infectoria was less virulent on pistachio than other Alternaria species.

In summary, we documented in this study that Alternaria fruit rot in blueberry in California is caused by a species complex of
Alternaria, including A. alternata, A. tenuissima, A. arborescens, $A$. infectoria, and $A$. rosae, with A. alternata and A. arborescens being the dominant species. A. infectoria and $A$. rosae were less virulent to blueberry fruit than other Alternaria species. As different species of Alternaria may respond to fungicides differently, the findings of this study will provide the basis for the development of chemical control practices targeting specific pathogens.

\section{ACKNOWLEDGMENTS}

The first author thanks the China Scholarship Council for the financial support (201206355002) during the one-year visit in the United States. We thank S. Pelham for collection of samples and isolation of the fungi, D. Margosan for assisting with microscopy, G. Phillips for assisting with molecular work, and T. Michailides for providing Alternaria reference isolates. Mention of trade names or commercial products in this article is solely for the purpose of providing specific information and does not imply recommendations or endorsement by the U.S. Department of Agriculture. USDA is an equal opportunity provider and employer.

\section{LITERATURE CITED}

Andrew, M., Peever, T. L., and Pryor, B. M. 2009. An expanded multilocus phylogeny does not resolve morphological species within the small-spored Alternaria species complex. Mycologia 101:95-109.

Anonymous. 2011. World blueberry production. http://faostat.fao.org

Cappellini, R. A., Ceponis, M. J., and Koslow, G. 1982. Nature and extent of losses in consumer grade samples of blueberries in greater. New York. HortScience 17:55-56.

Caruso, F. L., and Ramsdell, D. C. 2007. Compendium of Blueberry and Cranberry Diseases. American Phytopathological Society, St. Paul, MN.

Cline, W. O. 1996. Postharvest infection of highbush blueberries following contact with infested surface. Hortsciences 31:981-983.

Deng, J. X., Paul, N. C., Park, M. S., and Yu, S. H. 2012. Molecular characterization, morphology, and pathogenicity of Alternaria panax from araliaceous plants in Korea. Mycol. Prog. 12:383-396.

Greco, M., Patriarca, A., Terminiello, L., Fernandez Pinto, V., and Pose, G. 2012. Toxigenic Alternaria species from Argentinean blueberries. Int. J. Food Microbiol. 154:187-191.

Hall, T. A. 1999. BioEdit: A user-friendly biological sequence alignment editor and analysis program for Windows 95/98/NT. Nucl. Acids. Symp. Ser. 41:95-98.

Hong, S. G., Cramer, R. A., Lawrence, C. B., and Pryor, B. M. 2005. Alt al allergen homologs from Alternaria and related taxa: Analysis of phylogenetic content and secondary structure. Fungal Genet. Biol. 42:119129.

Jasnic, S., Marjanovic, Z., Vidic, M., Bagi, F., Budakov, D., Pavlovic, S., and Stojsin, V. 2011. Pathogenic, morphological and molecular characteristics of Alternaria tenuissima from soybean. Zbornik Matice Srpske za Prirodne Nauke:183-196.

Jimenez, M., Carpenter, F., Molinar, R. H., Wright, K., and Day, K. R. 2005. Blueberry research launches exciting new California specialty crop. Calif. Agric. 59:65-69.

Lambert, D. H. 1990. Postharvest fungi of lowbush blueberry fruit. Plant Dis. 74:285-287.

Lawrence, D. P., Gannibal, P. B., Dugan, F. M., and Pryor, B. M. 2014. Characterization of Alternaria isolates from the infectoria species-group and a new taxon from Arrhenatherum, Pseudoalternaria arrhenatheria sp. nov. Mycol. Prog. 13:257-276.

Lawrence, D. P., Gannibal, P. B., Peever, T. L., and Pryor, B. M. 2013. The sections of Alternaria: Formalizing species-group concepts. Mycologia 105:530-546.

Luan, Y. S., Feng, L., Xia, X. Y., and An, L. J. 2007. First report of Alternaria tenuissima causing disease on blueberry in China. Plant Dis. 91:464.

Ma, Z., Felt, D., and Michailides, T. J. 2003. Resistance to azoxystrobin in Alternaria isolates from pistachio in California. Pestic. Biochem. Physiol. 77:66-74.

Mehra, L. K., MacLean, D. D., Savelle, A. T., and Scherm, H. 2012. Postharvest disease development on southern highbush blueberry fruit in relation to berry flesh type and harvest method. Plant Dis. 97:213-221.

Milholland, R. D., and Jones, R. K. 1972. Postharvest decay of highbush blueberry fruit in North Carolina. Plant Dis Rep 56:118-122.

Page, R. D. M. 1996. TREEVIEW: An application to display phylogenetic trees on personal computers. Comput. Appl. Biosci. 12:357-358.

Posada, D., and Crandall, K. A. 1998. Modeltest: Testing the model of DNA substitution. Bioinformatics 14:817-818. 
Pryor, B. M., and Michailides, T. J. 2002. Morphological, pathogenic, and molecular characterization of Alternaria isolates associated with Alternaria late blight of pistachio. Phytopathology 92:406-416.

Ridgway, R. 1912. Color Standards and Color Nomenclature. Published by the Author, Washington, DC.

Roberts, R. G., Reymond, S. T., and Andersen, B. 2000. RAPD fragment pattern analysis and morphological segregation of small-spored Alternaria species and species groups. Mycol. Res. 104:151-160.

Ronquist, F., and Huelsenbeck, J. P. 2003. MRBAYES 3: Bayesian phylogenetic inference under mixed models. Bioinformatics 19:15721574.

Rosenzweig, N., Olaya, G., Atallah, Z. K., Cleere, S., Stanger, C., and Stevenson, W. R. 2008. Monitoring and tracking changes in sensitivity to azoxystrobin fungicide in Alternaria solani in Wisconsin. Plant Dis. 92: 555-560.

Simmons, E. G. 2007. Alternaria: An Identification manual. CBS Biodiversity Series 6. CBS Fungal Biodiversity Centre, Utrecht, The Netherlands.

Simmons, E. G., and Roberts, R. G. 1993. Alternaria themes and variations (73). Mycotaxon 48:109-140
Swofford, D. L. 2000. PAUP: Phylogenetic Analysis Using Parsimony. Sinauer Associates, Sunderland, MA.

Teviotdale, B. L., and Adaskaveg, J. E. 2002. Alternaria eaf pot. Pages 19-20 in: Compendium of Nut Crop Diseases in Temperate Zoness. B. L. Teviotdale, T. J. Michailides, and J. W. Pscheidt, eds. American Phytopathological Society, St. Paul, MN.

USDA-National Agricultural Statistics Service. 2014. Noncitrus fruits and nuts 2013 summary. http://usda.mannlib.cornell.edu/usda/nass/NoncFruiNu//2010s/2014/ NoncFruiNu-07-17-2014_revision.pdf.

Wang, T. Y., Zhao, J., Sun, P., and Wu, X. H. 2014. Characterization of Alternaria species associated with leaf blight of sunflower in China. Eur. J. Plant Pathol. 140:301-315.

Woudenberg, J. H., Groenewald, J. Z., Binder, M., and Crous, P. W. 2013. Alternaria redefined. Stud. Mycol. 75:171-212.

You, M. P., Lanoiselet, V., Wang, C. P., and Barbetti, M. J. 2013. First report of Alternaria leaf spot caused by Alternaria tenuissima on blueberry (Vaccinium corymbosum) in western Australia. Plant Dis. 98:423.

Zhu, X. Q., Chen, X. Y., and Guo, L. Y. 2011. Population structure of brown rot fungi on stone fruits in China. Plant Dis. 95:1284-1291. 